Yüzüncü Y1l Üniversitesi
Tarim Bilimleri Dergisi

Araştırma Makalesi (Research Article)

\title{
Bazı Soya (Glycine max L.) Çeşitlerinin IPBS Markörleriyle Moleküler Karakterizasyonu
}

\author{
Ahmet Metin KUMLAY ${ }^{1}$, Serap DEMIREL ${ }^{2}$, Fatih DEMIREL ${ }^{* 3}$, Bünyamin YILDIRIM ${ }^{4}$ \\ ${ }^{1,4}$ Iğdır Üniversitesi, Ziraat Fakültesi, Tarla Bitkileri Bölümü, Iğdır, Türkiye \\ ${ }^{2}$ Van Yüzüncü Yıl Üniversitesi, Fen Fakültesi, Moleküler Biyoloji ve Genetik Bölümü, Van, Türkiye \\ ${ }^{3}$ Iğdır Üniversitesi, Ziraat Fakültesi, Tarımsal Biyoteknoloji Bölümü, Iğdır, Türkiye \\ ${ }^{1}$ https://orcid.org/0000-0001-9765-8674 ${ }^{2}$ https://orcid.org/0000-0002-3102-4924 ${ }^{3}$ https://orcid.org/0000-0002-6846-8422 \\ ${ }^{4}$ https://orcid.org/0000-0003-2463-6989 \\ *Sorumlu yazar e-posta: drfdemirel@gmail.com
}

\section{Makale Bilgileri}

Geliş: 15.10 .2020

Kabul: 25.11.2020

Online Yayınlanma 30.03.2021

DOI: $10.29133 /$ yyutbd.811158

\section{Anahtar kelimeler}

Genetik ilişki,

Glycine max L., IPBS,

Islah.
Öz: Küresel 1sınma ve insan popülasyonunun sürekli artması besin kaynağı üzerinde baskı oluşturmaktadır. Soya fazlaca protein ve yağ içermesinden dolayı insan beslenmesinde önemli rol oynamaktadır. Bu çalışmada 12 soya çeşidinin (Nova, Nazlican, SA88, Ataem7, Arısoy, A3127, Türksoy, Adasoy, Yemsoy, ANP2018, Yeşilsoy ve Samsoy) 6 IPBS markörü ile genetik ilişkisi incelenmiştir. IPBS analizi sonucuna göre toplam 44 polimorfik bant elde edilmiş olup ortalama polimorfizm oran $1 \% 85.83$ olmuştur. Primer başına elde edilen ortalama polimorfik bant sayısı 7.33 olarak belirlenmiştir. Geneotipler arasında Dice benzerlik indeksi 0.1 ile 0.9091 arasında değişmiş olup ortalama benzerlik indeksi 0.4506 olarak hesaplanmıştır. Analizlerin sonuçlarına göre, en yakın akrabalık gösteren genotiplerin Yeşilsoy ile Arısoy çeşitleri iken, en az benzeyen genotiplerin ise Samsoy ile Yemsoy çeşitleridir. Sonuç olarak, IPBS markörleri soya 1slahı programlarında uygun ebeveynlerin seçiminde genotipleri karakterize etmek için etkili bir şekilde kullanılabilir.

\section{Molecular Characterization of Some Soybean (Glycine max L.) Varieties}

\section{Article Info}

Received: 15.10 .2020

Accepted: 25.11.2020

Online Published 30.03.2021

DOI: 10.29133/yyutbd.811158

\section{Keywords}

Genetic diversity, Glycine max L., IPBS,

Breeding.

\begin{abstract}
Global warming and the continuous increasing in human population have adverse effects on the food source. Soybean plays a significant role in human nutrition due to its high protein and fat content. In this study, the genetic relationship of 12 soybean varieties (Nova, Nazlican, SA88, Ataem7, Arısoy, A3127, Türksoy, Adasoy, Yemsoy, ANP2018, Yeşilsoy and Samsoy) was investigated using 6 IPBS markers. According to the results of the IPBS analysis, totally 44 polymorphic bands were obtained and the average polymorphism rate was $85.83 \%$. The average number of polymorphic bands obtained per primer was determined as 7.33. The Dice similarity index between genotypes varied between 0.1 and 0.9091 with the average being 0.4506 . According to the results of the analysis, the genotypes showing the closest relationship are Yeşilsoy and Arısoy varieties, while the farthest genotypes are Samsoy and Yemsoy. As a result, IPBS markers can be used effectively to characterize genotypes in the selection of suitable parents in soybean breeding programs.
\end{abstract}




\section{Giriş}

Rosales takımının Leguminosae familyasından, Papilionaceae alt familyasının Glycine cinsine ait bir bitki olan soyanın ana vatanı Doğu Asya'dır. Soya bitkisinin milattan önce gıda üretimi amacıyla ekiminin yapıldığı bildirilmektedir. Soya (Glycine max L.), tek yıllık bitkiler arasında dünya bitkisel yağ üretim ve tüketiminde ilk sırada yer alan önemli bir yağ bitkisidir (Arığlu, 2007). Soya aynı zamanda bir baklagil bitkisi olduğu için ihtiyacı olan azotu havanın serbest azotunu kullanarak karşılamakta ve kendinden sonra kullanılacak bitkiler için toprağa azot bağlamaktadır. Bu yüzden iyi bir münavebe bitkisi olarak kabul edilmektedir (Kökten, 2014).

Yazlık ekimi yapılan ve tek yıllık olan soya bitkisinin tohumlarında ortalama \%36-40 protein, \%18-24 yağ (Omega-3 ve benzeri yağ asitleri), B1, B2, K ve E vitaminleri, Zn, Fe ve Ca elementleri, $\% 27$ karbonhidrat ve \%18 madensel maddeler bulunmaktadır. Ayrıca, soya küspesi hayvan beslenmesinde yem rasyonları için önemli bir yer tutmaktadır (Sarımehmetoğlu, 2006; Arığlu, 2007). Diğer taraftan soya bitkisi bisküvi, çikolata, hazır çorba gibi birçok gıda maddesinin yapımında da kullanılmaktadır (Polat, 2015).

Soya fasulyesi insan beslenmesinde önemli yer tutmaktadır. İnsan kaynaklı soya tüketimi giderek artmasının yanında, soyanın birçok alanda sanayi ham maddesi olarak kullanımı da artmaktadır. 1980'li yıllarda ABD'de biyodizel yakıt olarak kullanılabileceği de saptanmış ve yenilenebilir enerji kaynaklarıyla beraber kullanımı üzerine dikkat çekilmiştir (Kinney ve Clemente, 2004).

Gerek sanayi hammaddesi gerekse beslenme olarak önemli bir yere sahip olan soya bitkisinin dünyadaki önemi her geçen gün artmasına rağmen, Türkiye'de sulamaya bağlı olarak uygun yetişme ortam koşullarını bulabilmesine karşın yeterli ilgiyi bulamamıştır. Farklı iklim koşullarının hüküm sürdüğü Türkiye'de bu bitkinin yaygın olarak ekilmesi ve ülke ticaretinde önemli bir yere sahip olması için gerekli adımların atılması gerekmektedir. Bu yüzden soya bitkisinin ekim alanlarının genişletilmesi, üretim ve veriminin arttırılması için Türkiye’deki mevcut durumun ve bitkinin ortam koşullarının saptanarak, potansiyel soya bitkisi yetiştirilebilecek alanlarının belirlenmesi gereklidir. Ayrıca, soya bitkisinden, yeni ıslah materyallerinin geliştirilmesi, genetik akrabalık düzeylerinin belirlenmesi ve gen havuzunun oluşturulması önem arz etmektedir. Bu kapsamda, agromorfolojik özellikler ile genetik özelliklerin moleküler tanımlanması ıslah çalışmalarına hız kazandırırken genetik çeşitliliğin ortaya konulması yeni 1slah materyallerinin geliştirilmesi için önem taşımaktadır (Escribano ve ark., 1998).

Bir bitkiye ait çeşitlerin tanımlanması ve tescili, esas olarak morfolojik ve fizyolojik özelliklere dayanmaktadır. Bu tanımlayıcılar yararlı olsalar da sayıları sınırlıdır ve çevresel faktörlerden etkilenebilirler. Moleküler belirteçler, çeşitlerin morfolojik ve fizyolojik karakterizasyonunun yararlı bir tamamlayıcısıdır, çünkü bunlar bol miktarda bulunur, doku veya çevresel etkilerden bağımsızdır ve bitki gelişiminin erken aşamalarında genotip tanımlamasına izin verir. Çeşitlerin moleküler karakterizasyonu aynı zamanda genetik çeşitliliğin zamanla azalması olarak tanımlanan potansiyel genetik erozyonu değerlendirmek için de geniş ölçüde kullanılmaktadır (Manifesto ve ark., 2001).

Az miktar DNA ile yüksek polimorfizm veren dominant markör teknikleri (RAPD, ISSR, IPBS gibi) ekonomik yönden ucuz oldukları gibi çabuk sonuç verdikleri ve daha az iş gücü gerektirdiği için tercih edilmektedir (Yorgancılar ve ark., 2015; Demirel, 2020; Koçak ve ark., 2020; Nkongolo ve ark., 2020). Kalendar ve ark. (2010)'nın geliştirdiği DNA-IPBS (Inter-Primer Binding Site) moleküler markörleri farklı LTR (long terminal repeat) sekanslarını tanımlamak için kullanılan ve çeşitler arasında polimorfizmi doğrudan görselleştiren bir metottur. IPBS markörleri klon analizlerinde, genetik çeşitlilik analizlerinde ve filogenetik çalışmalarda başarılı bir şekilde uygulanmıştır (Smýkal ve ark., 2011; Baránek ve ark., 2012; Gailite ve Rungis, 2012). IPBS, polimorfizmi açığa çıkarma konusunda eşit veya daha yüksek kapasiteye sahiptir ve tür içi ve türler arası çeşitliliği belirlemek için büyük bir potansiyel sunmaktadır (Andeden ve ark., 2013).

Bu çalışmada soya genotiplerinin genetik çeşitliliği DNA temelli IPBS moleküler markörler ile PCR (Polimeraz Zincir Reaksiyonu) yöntemi kullanılarak incelenmiştir. Bu araştırmayla, genetik çeşitliliğin belirlenmesi ile kullanılacak markörlerin soya genotipleri üzerindeki tanımlamanın belirlenmesi hedeflenmiştir. Bununla birlikte, IPBS markörleri ile soya (Glycine max L.) genotipleri üzerinde çalışılmamıştır. Dolayısıyla bu çalışmada, IPBS markör sisteminin soyada kullanılabilirliği 
belirlenerek, markörlerin ayırt ediciliğini belirlemek için markörlere ait PIC gibi bazı parametreler de hesaplanmıştır.

\section{Materyal ve Yöntem}

Çalışmada 12 adet (Nova, Nazlican, SA88, Ataem7, Arısoy, A3127, Türksoy, Adasoy, Yemsoy, ANP2018, Yeşilsoy ve Samsoy) soya çeşidi kullanılmıştır. Araştırma Erciyes Üniversitesi Genom ve Kök Hücre Merkezi Bitki Biyoteknolojisi biriminde yürütülmüştür. Materyaller Iğdır Üniversitesi Tarla Bitkileri Bölümü bünyesinden temin edilmiştir.

DNA izolasyonu, genç yapraklardan $0.4 \mathrm{~g}$ kullanılarak DNA kiti aracılığıyla gerçekleştirilmiştir (Fermentas, Maryland, USA). İzole edilen DNA'ların miktarları 230/280 nm dalga boyunda BioSpec-nano Shimadzu Biotech spektrofotometre cihazı kullanılarak ölçülmüştür. Miktarı ölçülen DNA'lar PCR analizi için $5 \mathrm{ng} / \mu 1$ olacak şekilde hazırlanmıştır. PCR kokteyli toplamda $20 \mu 1$ olacak şekilde hazırlanmıştır. PCR işleminde reaksiyon için $94{ }^{\circ} \mathrm{C}$ 'de 1 dakika 1 döngü, $94^{\circ} \mathrm{C}$ 'de 45 saniye markör bağlanma sıcaklığında 45 saniye $72{ }^{\circ} \mathrm{C}$ 'de 1 dakika 42 döngüyle yapıldıktan sonra 72 ${ }^{\circ} \mathrm{C}$ 'de 5 dakika 1 döngü basamakları ile sonlandırılmıştır (Demirel, 2020).

PCR işlemi sonrasında çoğaltılan DNA'lar TBE tampon içerisinde \%2'lik agaroz jel üzerinde elektroforez kullanılarak 120 V'da 3 saat yürütülmüştür. Elektroforez işleminde kuyulara PCR ürünü, $2 \mu 1$ yükleme boyası ve 100-3000 bç'lik 100 bp DNA Ladder H3 RTU (GeneDirex) eklenmiştir (Cat. No. DM003-R500). Elektroforez işlemi sonunda agaroz jeller UV ışını altında fotoğrafları çekilip kayıt edilmiştir.

Görüntüler incelenerek bant profilleri binary olarak (bant varlığında "1", bant yokluğunda " 0 ”) kodlanmıştır. Kullanılan markörlere ait I (Shannon bilgi içeriği) ve H (Nei'nin gen çeşitliliği) değerleri GENALEX V6.5 programı kullanılarak belirlenmiştir (Shannon, 1948; Nei, 1973; Peakall ve Smouse, 2006). PIC (polimorfizm bilgi içeriği) değeri PowerMarker V3.25 programı kullanılarak hesaplanmıştır (Liu and Muse, 2005). Genotipler arasındaki benzerlik katsayıları hesaplanarak (Dice, 1945) UPGMA (Aritmetik Ortalamayı Kullanan Ağıllıksız Çift Grup Metodu) metodu ile dendogram NTSYS-pc V2.11 programı kullanılarak oluşturulmuştur. Ayrıca, Eigen vektörü hesaplanarak iki boyutlu ve üç boyutlu grafikler elde edilmiştir (Rohlf, 2000).

\section{Bulgular}

Çalışmada 12 soya çeşidi 6 IPBS markörleri kullanılarak polimorfizm araştırılmıştır. Markörlere ait bilgiler Çizelge 1'de verilmiştir. Çalışmada elde edilen toplam 49 banttan 44'ü polimorfik bant oluşturmuştur. Ortalama polimorfik bant sayıs1 7.33'dür. En yüksek polimorfik bant (15) veren IPBS-2080 markörüdür ve polimorfizm oranı \%100'dür. En düşük polimorfizm oranı \%50 olup IPBS-2384 markörüne aittir.

Çizelge 1. IPBS markörlerinin karakterizasyon değerleri

\begin{tabular}{|c|c|c|c|c|c|c|c|c|}
\hline \multicolumn{2}{|r|}{ Markör Bilgileri } & \multicolumn{3}{|c|}{ Bantların Bilgileri } & \multicolumn{4}{|c|}{ Çeşitlilik Değerleri } \\
\hline Markör Adı & $\begin{array}{c}\text { Markör Sekansları } \\
\text { 5'-3' } \\
\end{array}$ & Sicaklık & $\begin{array}{c}\text { Toplam } \\
\text { Bant }\end{array}$ & $\begin{array}{c}\text { Polimorfik } \\
\text { Bant }\end{array}$ & $\mathrm{P} \%$ & $\mathrm{I}$ & $\mathrm{H}$ & PIC \\
\hline IPBS2384 & GTAATGGGTCCA & 45 & 6 & 3 & 50 & 0.67 & 0.48 & 0.36 \\
\hline IPBS2382 & TGTTGGCTTCCA & 45 & 4 & 3 & 75 & 0.32 & 0.21 & 0.17 \\
\hline IPBS2381 & GTCCATCTTCCA & 45 & 8 & 8 & 100 & 0.47 & 0.31 & 0.25 \\
\hline IPBS2231 & ACTTGGATGCTGATACCA & 55 & 6 & 6 & 100 & 0.31 & 0.21 & 0.16 \\
\hline IPBS2080 & CAGACGGCGCCA & 50 & 15 & 15 & 100 & 0.31 & 0.18 & 0.16 \\
\hline IPBS2077 & CTCACGATGCCA & 45 & 10 & 9 & 90 & 0.44 & 0.27 & 0.23 \\
\hline Toplam & & & 49 & 44 & & & & \\
\hline Ortalama & & & 8.16 & 7.33 & 85.83 & 0.42 & 0.28 & 0.22 \\
\hline
\end{tabular}

Çalışmamızdan elde edilen verilere göre en yüksek I değeri IPBS-2384 (I=0.67) marköründe, en düşük ise IPBS-2080 (I=0.31) ve IPBS-2231 ( $\mathrm{I}=0.31$ ) markörlerinde görülmüştür. Markörlere ait ortalama I değeri ise 0.42 olarak hesaplanmıştır.

$\mathrm{Bu}$ araştırma sonucunda en yüksek H değeri IPBS-2384 (H=0.48) marköründe, en düşük ise IPBS-2080 $(\mathrm{H}=0.18)$ marköründe oluşmuştur. Markörlere ait ortalama H değeri ise 0.42 olarak hesaplanmıştır. 
PIC, mevcut her bir bandın ilişki frekanslarını hesaba kattı̆g için, ham bant sayısından biraz daha iyi bir çeşitlilik tahmini sağlar (Cömertpay ve ark., 2012). Bu nedenle bu sonuçlar, güvenilir genotip ayrımı için gerekli lokusların sayısını azaltmada ve en bilgilendirici markörlerin saptanmasında bize yardımcı olmaktadır. Çalışmamızda en yüksek PIC değeri IPBS-2384 (PIC=0.36) marköründe, en düşük ise IPBS-2080 (PIC=0.16) ve IPBS-2231 (PIC=0.16) markörlerinde görülmüştür. Markörlere ait ortalama PIC değeri ise 0.22 olarak hesaplanmıştır.

Soya genotiplerine ait Dice benzerlik indeksleri Çizelge 2'de verilmiştir. Genotiplerin benzerlik düzeyleri 0.1 ile 0.9091 arasında değişmiş olup ortalama benzerlik değeri 0.4506 olarak hesaplanmıştır. Birbirine en çok benzeyen soya genotipleri Yeşilsoy ile Arısoy çeşitleri iken birbirine en uzak genotipler Samsoy ile Yemsoy çeşitleri arasında olduğu belirlenmiştir.

Çizelge 2. DICE benzerlik katsayıları

\begin{tabular}{|c|c|c|c|c|c|c|c|c|c|c|c|}
\hline & Nova & Nazlican & SA88 & Ataem7 & Arisoy & A3127 & Türksoy & Adasoy & Yemsoy & ANP2018 & Yeşilsoy \\
\hline Nazlican & 0.4211 & 1 & & & & & & & & & \\
\hline SA88 & 0.3529 & 0.5000 & 1 & & & & & & & & \\
\hline Ataem7 & 0.1429 & 0.4000 & 0.7273 & 1 & & & & & & & \\
\hline Arısoy & 0.6000 & 0.7368 & 0.5882 & 0.4286 & 1 & & & & & & \\
\hline A3127 & 0.5000 & 0.2105 & 0.4706 & 0.1429 & 0.4000 & 1 & & & & & \\
\hline Turksoy & 0.4762 & 0.6000 & 0.6667 & 0.4000 & 0.6667 & 0.381 & 1 & & & & \\
\hline Adasoy & 0.5217 & 0.7273 & 0.5000 & 0.3529 & 0.8696 & 0.3478 & 0.7500 & 1 & & & \\
\hline Yemsoy & 0.3846 & 0.6400 & 0.3478 & 0.3000 & 0.6923 & 0.2308 & 0.5185 & 0.7586 & 1 & & \\
\hline ANP2018 & 0.3810 & 0.7273 & 0.4444 & 0.3529 & 0.7619 & 0.1905 & 0.5455 & 0.7500 & 0.7407 & 1 & \\
\hline Yesilsoy & 0.5455 & 0.6667 & 0.5263 & 0.3750 & 0.9091 & 0.3636 & 0.6087 & 0.8000 & 0.7143 & 0.7826 & 1 \\
\hline Samsoy & 0.2857 & 0.1538 & 0.3636 & 0.5000 & 0.1429 & 0.1429 & 0.1333 & 0.1176 & 0.1000 & 0.1333 & 0.1250 \\
\hline
\end{tabular}

Dice benzerlik indeksinden yararlanarak UPGMA metodu ile kümeleme analizi yapılmıştır ve bunların dendrogramı (Şekil 1) elde edilmiştir. Elde edilen dendograma göre genotipler iki ana kümeye ayrılmıştır (A ve B). Samsoy genotipi A kümesi içerisinde yer alarak diğer genotiplerden ayrılmıştır. B kümesi kendi içerisinde iki kümeye ayrılmıştır (C ve D). D kümesi içerisinde Nova ve A3127 genotipleri kendi arasında bir grup oluşturmuştur. C kümesi de kendi içerisinde $\mathrm{E}$ ve $\mathrm{F}$ kümelerine ayrılmıştır. E kümesi içerisinde SA88 ve Ataem7 genotipleri bir grup oluşturmuştur. F kümesi içerisinde geriye kalan Türksoy, Yemsoy, ANP2018, Adasoy, Yeşilsoy ve Arısoy genotiplerinin kendi aralarında gruplandığı tespit edilmiştir.

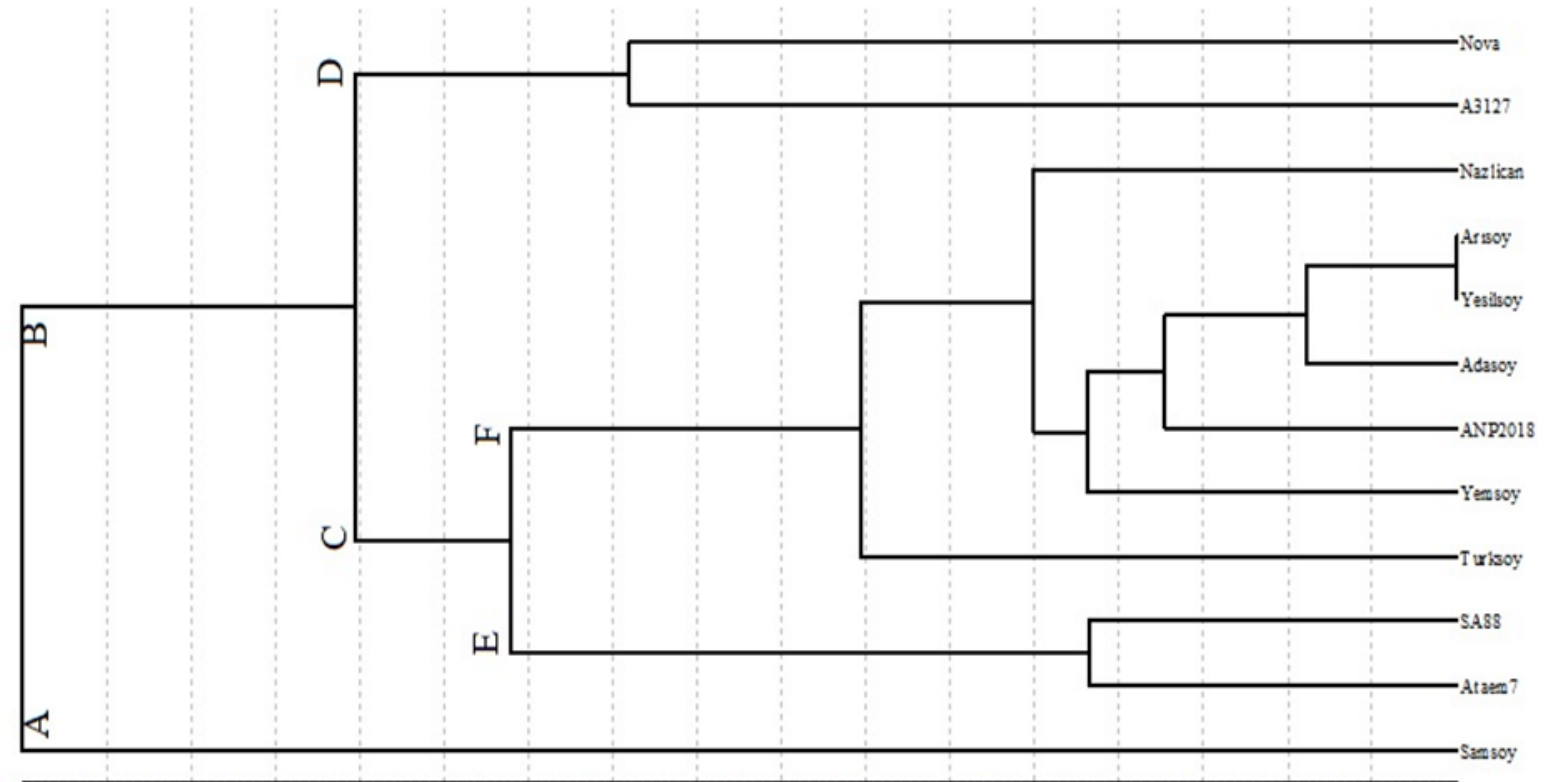

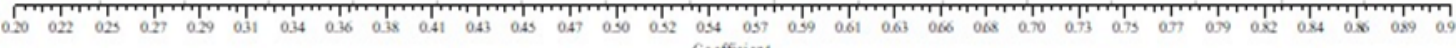

Şekil 1. UPGMA dendogram1. 
Genotipleri arasındaki genetik farklılığı ortaya çıkarmak için moleküler verilere dayalı Temel Bileşen Analizi (PCA: Principal Component Analysis) yapılmıştır. PCA sonucuna göre ilk üç ana bileşenin eklemeli toplamı \% 76.74 olarak belirlenmiştir (Çizelge 3).

Çizelge 3. İlk üç ana faktörün eigen değerleri

\begin{tabular}{cccc}
\hline Ana Bileşenler & Eigen Değerleri & Yüzdeleri (\%) & Eklemeli Toplamları (\%) \\
\hline 1 & 6.53 & 54.45 & 54.45 \\
2 & 1.53 & 12.78 & 67.23 \\
3 & 1.14 & 9.51 & 76.74 \\
\hline
\end{tabular}

Genetik çeşitlilik modelini analiz etmek için kümeleme tekniklerinden yararlanılmaktadır. Kümeleme teknikleri karmaşık ve çok boyutlu çeşitlilik modelleri sunabilirken, temel koordinat ve bileşen analizleri iki boyutlu ve üç boyutlu sunumlarla kümeleri tanımlamak için birlikte kullanılabilmektedir (Ganeva ve ark., 2010; Gurcan ve ark., 2017).

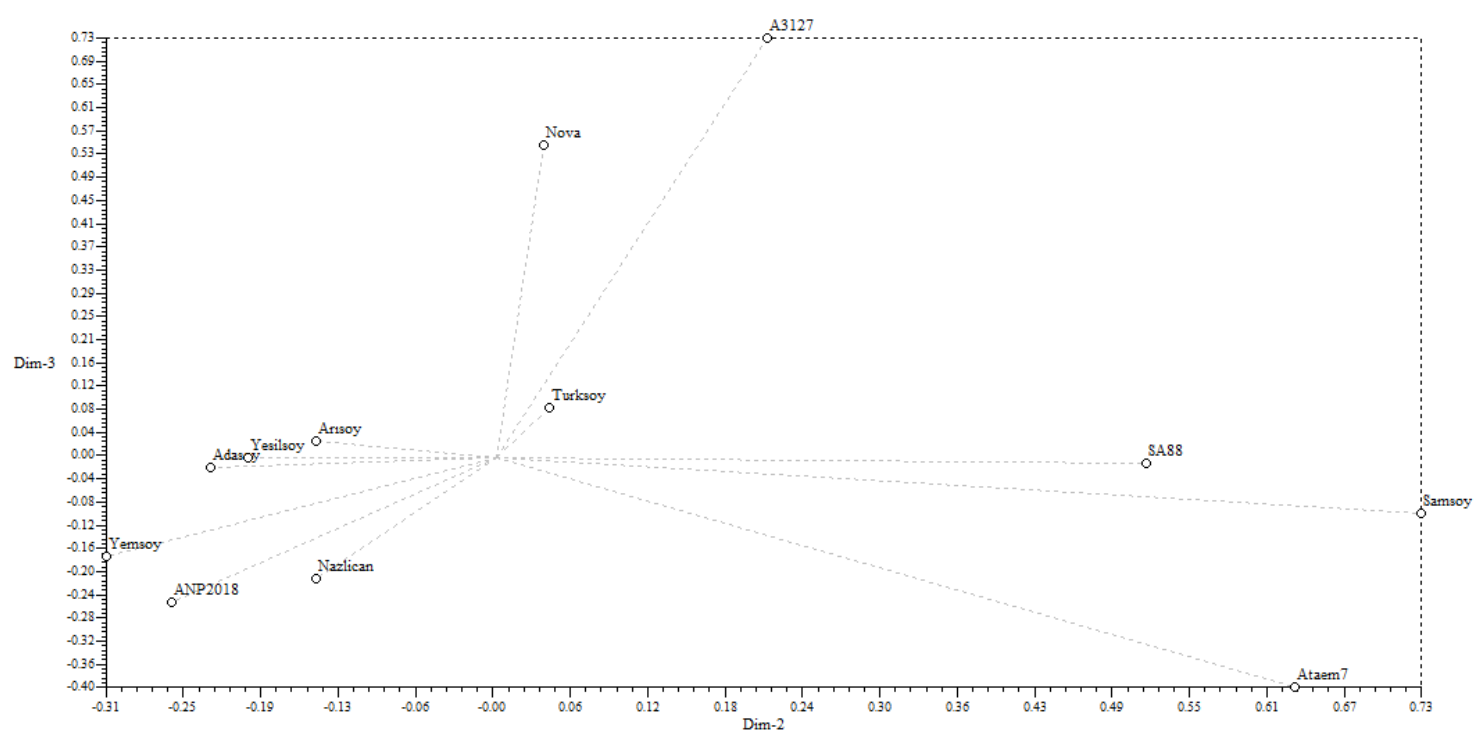

Şekil 2. İki boyutlu (2D) temel bileşenler (PCA) grafiği.

Temel bileşen analizi (PCA) yapılarak iki boyutlu (2D) ve üç boyutlu (3D) grafikler elde edilmiştir. 2D grafiği Şekil 2'de, 3D grafiği de Şekil 3'de görülmektedir. 2D grafikte SA88, Samsoy ve Ataem7 bir arada kümelenmiş gibi gözükse de 3D grafikte Samsoy genotipi Ataem ve SA88 genotiplerinden ayrı gruplanmıştır. Dendogramda da (Şekil 1) Samsoy diğer genotiplerinden ayrılmış ve A kümesi içerisinde yer almıştır. Aynı şekilde, Ataem ve SA88 genotipleri de 3D grafik ile benzer şekilde ayrı gruplanmış olup dendogramda (Şekil 1) E kümesi içerisinde yer almıştır. Dendorgamda (Şekil 1) Nova ve A3127 D kümesi içerisinde yer alsa da 3D grafik incelendiğinde Nova genotipinin A3127 genotipinden farklılık gösterdiği gözlenmektedir. Dendogramda (Şekil 1) Türksoy genotipi F kümesi içerisinde yer alsa da, 2D ve 3D grafikleri incelendiğinde $\mathrm{F}$ kümesini oluşturan diğer genotiplerden farklı noktada yer aldığı belirlenmiştir. 


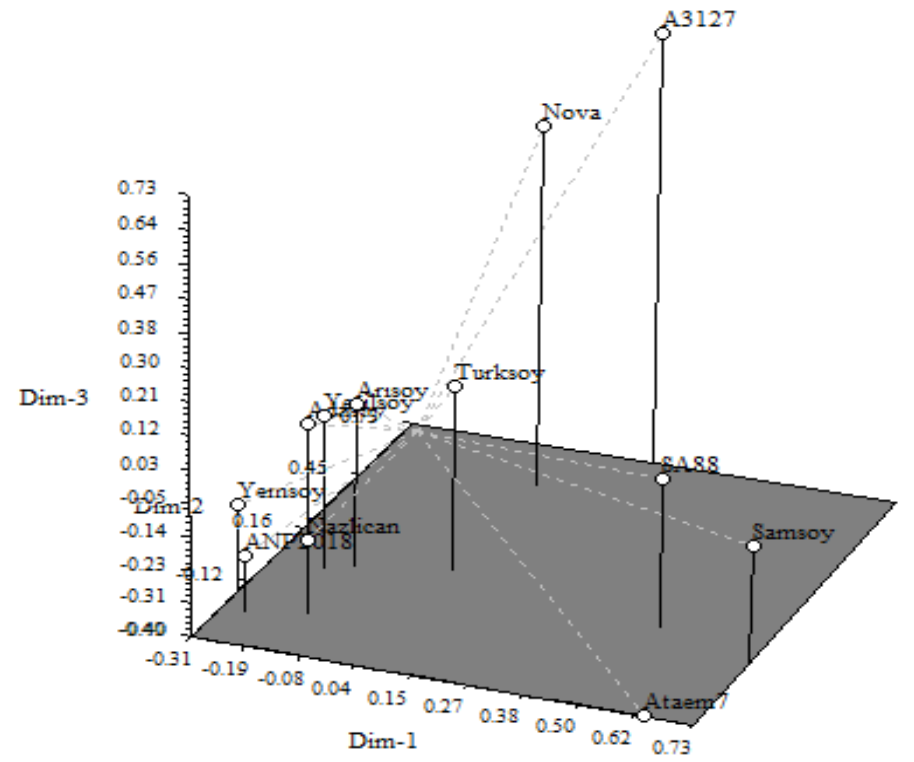

Şekil 3. Üç boyutlu (3D) temel bileşenler (PCA) grafiği.

\section{Tartışma ve Sonuç}

Çalışmamızda toplam 6 IPBS markörü kullanılmış ve 12 soya çeşidinde toplam 44 polimorfik bant saptanmıştır. $\mathrm{Bu}$ çalışmada kullanılan soya çeşitlerinin moleküler karakterizasyonu IPBS markörleri aracılığıyla gerçekleştirilmiştir. DICE benzerlik katsayıları belirlenmiş ve birbiri ile en yakın akrabalık gösteren genotiplerin Yeşilsoy ile Arısoy çeşitleri olduğu belirlenmiştir. Akrabalık yönünden birbirine en az benzeyen genotiplerin ise Samsoy ile Yemsoy çeşitleri olduğu tespit edilmiştir.

Ude ve ark. (2003) Çin, Japonya ve Kuzey Amerika'dan topladıkları toplam 190 soya genotipini AFLP markörü ile analiz etmişler ve \%27 (polimorfizm oranı) gibi çok düşük bir rakam belirlemişlerdir. Brick ve Sivalop (2001), farklı ekolojik ve coğrafi kökenlerden 19 soya fasulyesi çeşidini incelemek için 5 ISSR markörlerini kullanarak \%75 polimorfizm tespit ettiklerini raporlamışlardır. Bizim çalışmamızda kullandığımız IPBS markörleri ise bu çalışmalardan elde dilen verilere göre soya çeşitlerinde yüksek polimorfizm göstermiştir. Stathi ve ark. (2020), Cicer graecum'da ISSR markörlerini kullanarak elde ettikleri ortalama I değerini 0.31 olarak rapor etmişlerdir. Mevcut çalışmamızdaki I değeri Stathi ve ark. (2020)'ın elde ettikleri sonuçtan yüksektir. Baloch ve ark. (2015), IPBS markörleri kullanarak bezelye (Pisum sativum L.) genotiplerinde ortalama H değerini 0.26 olarak, Andeden ve ark. (2013) ise nohut genotiplerinde IPBS markörleri kullanarak ortalama $\mathrm{H}$ değerini 0.27 , ISSR markörlerini kullanarak ortalama $\mathrm{H}$ değerini 0.29 olarak bulduklarını bildirmişlerdir. Bizim çalışmamızdaki ortalama $\mathrm{H}$ değeri literatürdeki çalışmalar ile benzerlik göstermiştir. Baloch ve ark. (2015) bezelye (Pisum sativum L.) genotiplerini IPBS yöntemiyle incelemişler ve ortalama PIC değeri (0.61) bizim çalışmamızdan yüksek olduğu belirlenmiştir. $\mathrm{Bu}$ durum bizim çalışmamızdaki allelik farklılığın düşük olduğunu göstermektedir. Chowdhury ve ark. (2002) RAPD markörleri kullanarak soya genotiplerinde ortalama Dice benzerlik katsayılarını 0.449 olarak bildirmişlerdir. Çalışmamızda kullandığımız soya genotiplerinin ortalama Dice değerleri ile örtüşmektedir.

Islah programları yapılırken belirli bir genetik özelliğin seçilmesiyle sonuca varıldı̆̆ bilinmektedir. Bu durum, soya gibi kültürü yapılan bitkilerde çeşitler arasında benzer genetik yapıların oluşmasına neden olabilmektedir. IPBS tekniği, soya yetiştirme programları için ebeveynlerin belirlenmesine yardımcı olmak için ucuz ve uygun bir tekniktir. Bu çalışma ülkemizde soya bitkisinde IPBS markörleri ile genetik ilişkinin değerlendirildiği ilk çalışma niteliğine sahip olup daha sonra soyada yapılacak genetik ve moleküler çalışmalara katkı sağlayacaktır. Bu çalışmadan elde edilen sonuçlar, soya fasulyesi ıslahçılarının genetik çeşitlilik hakkında bilgi edinmelerine yardımcı olmasının yanında, soyanın genetik temelini genişletmek için kullanılacak stratejilerin geliştirilmesi adına bilgi sağlayacaktır. 


\section{Teşekkür}

Bu çalışmanın (2019-FBE-A09) gerçekleştirilmesinde maddi imkanları destekleyen Iğdır Üniversitesi Bilimsel Araştırma Projeleri (BAP) Birimine katkılarından dolayı teşekkür ederiz. Ayrıca laboratuvar çalışmalarındaki yardımları için Moleküler Biyolog (doktora öğrencisi) Aybüke Erol'a da teşekkür ederiz.

\section{Kaynakça}

Andeden, E. E., Baloch, F. S., Derya, M., Kilian, B., \& Özkan, H. (2013). iPBS-Retrotransposonsbased genetic diversity and relationship among wild annual Cicer species. Journal of Plant Biochemistry and Biotechnology, 22(4), 453-466.

Arığlu, H. H. (2007). Yă̆ Bitkileri Yetiştirme ve Islahı Ders Kitapları. Çukurova Üniversitesi Ziraat Fakültesi Ofset Atölyesi, Adana.

Baloch, F. S., Alsaleh, A., de Miera, L. E. S., Hatipoğlu, R., Çiftçi, V., Karaköy, T., Yıldız, M., \& Özkan, H. (2015). DNA based IPBS-retrotransposon markers for investigating the population structure of pea (Pisum sativum) germplasm from Turkey. Biochemical Systematics and Ecology, 61, 244-252.

Baránek, M., Meszaros, M., Sochorova, J., Cechova, J., \& Roddova, J. (2012). Utility of retrotransposon-derived marker systems for differentiation of presumed clones of the apricot cultivar Velkopavlovicka. Scientia Horticulturae, 143, 1-6.

Brick, A. F., \& Sivolap, Y. M. (2001). Molecular genetic identification and certification of soybean (Glycine max L.) cultivars. Russian Journal of Genetics, 37(9), 1061-1067.

Chowdhury, A. K., Srinives, P., Tongpamnak, P., Saksoong, P., \& Chatwachirawong, P. (2002). Genetic relationship among exotic soybean introductions in Thailand: Consequence for varietal registration. Science Asia, 28, 227-239.

Cömertpay, G., Baloch, F. S., Kilian, B., Ülger, A. C., \& Özkan, H. (2012). Diversity assessment of Turkish maize landraces based on fluorescent labelled SSR markers. Plant Molecular Biology Reporter, 30(2), 261-274.

Demirel, F. (2020). Bazı siyez buğdaylarının ISSR Markörleri ile karakterizasyonu. Journal of Agriculture, 3(2), 33-39.

Dice, L. R., (1945). Measures of the amount of ecologic association between species. Ecology, 26, 297-302.

Escribano, M. R., Santalla, M., Casquero, P. A., \& De Ron, A. M. (1998). Patterns of genetic diversity in landraces of commonbean (Phaseolus vulgaris L.) from Galicia. Plant Breeding, 117(1), 49-56.

Gailite, A., \& Rungis, D., (2012). An initialinvestigation of the taxonomic status of Saussurea esthonica Baer ex Rupr. utilising DNA markers and sequencing. Plant Systematics and Evolution, 298, 913-919.

Ganeva, G., Korzun, V., Landjeva, S., Popova, Z., \& Christov, N. K. (2010). Genetic diversity assessment of Bulgarian durum wheat (Triticum durum Desf.) landraces and modern cultivars using microsatellite markers. Genetic Resources and Crop Evolution, 57(2), 273-285.

Gurcan, K., Demirel, F., Tekin, M., Demirel, S., \& Akar, T. (2017). Molecular and agromorphological characterization of ancient wheat landraces of Turkey. BMC Plant Biology, 17(1), 171.

Kalendar, R., Antonius, K., Smýkal, P., \& Schulman, A. H. (2010). iPBS: a universal method for DNA fingerprinting and retrotransposon isolation. Theoretical and Applied Genetics, 121(8), 1419-1430.

Kinney, A. J. A., \& Clemente, T. E. (2004). Modifying soybean oil for enhanced performance in biodisel blends. Fuel Processing Technology, 86(10), 1137-1147.

Koçak, M., Karataş, M., Alp, Ş., Baloch, F., \& Yıldız, M. (2020). Van gölü havzasından toplanan terslale (Fritillaria imperialis L.) genotiplerinde genetik farkl1lı̆̆ı iPBS retrotranspozon markırları ile belirlenmesi. Yüzüncü Yll Üniversitesi Tarım Bilimleri Dergisi, 30(2), 398-406.

Kökten, K., Seydosoğlu, S., Kaplan, M., \& Boydak, E., (2014). Forage nutritive value of soybean varieties. Legume Research-An International Journal, 37(2), 201-206. 
Liu, K., \& Muse, S. V. (2005). PowerMarker: an integrated analysis environment for genetic marker analysis. Bioinformatics, 21(9), 2128-2129.

Manifesto, M. M., Schlatter, A. R., Hopp, H. E., Suárez, E. Y., \& Dubcovsky, J. (2001). Quantitative evaluation of genetic diversity in wheat germplasm using molecular markers. Crop science, 41(3), 682-690.

Nei, M. (1973). Analysis of gene diversity in subdivided populations. Proceedings of the National Academy of Sciences, 70(12), 3321-3323.

Nkongolo, K., Alamri, S., \& Michael, P. (2020). Assessment of Genetic Variation in Soybean (Glycine max) Accessions from International Gene Pools Using RAPD Markers: Comparison with the ISSR System. American Journal of Plant Sciences, 11(9), 1414-1428.

Peakall, R. O. D., \& Smouse, P. E. (2006). GENALEX 6: genetic analysis in Excel. Population genetic software for teaching and research. Molecularecologynotes, 6(1), 288-295.

Polat, N. (2015). Bazı soya türevlerinin sığır ve tavuk etlerinin emülsiyon karakteristikleri üzerine etkisi. (PhD), Selcuk University, Institute of Natural and Applied Science, Konya, Turkey.

Rohlf, J. F. (2000). NTSYS-pc: Numerical Taxonomy and Multivariate Analysis System. Exeter Software, Setauket, New York.

Sarımehmetoğlu, O. (2006). The determination of some important quality characteristics of soybean grown in farmer condotions in Çukurova region. Master Thesis. Cukurova University, Institute of Natural and Applied Science, Adana, Turkey.

Shannon, C. E. (1948). A mathematical theory of communication. The Bell system technical journal, 27(3), 379-423.

Smýkal, P., Bačová-Kerteszová, N., Kalendar, R., Corander, J., Schulman, A. H., \& Pavelek, M. (2011). Genetic diversity of cultivated flax (Linum usitatissimum L.) germplasm assessed by retrotransposon-based markers. Theoretical and Applied Genetics, 122(7), 1385-1397.

Stathi, E., Kougioumoutzis, K., Abraham, E. M., Trigas, P., Ganopoulos, I., Avramidou, E. V., \& Tani, E. (2020). Population genetic variability and distribution of the endangered Greek endemic Cicer graecum under climate change scenarios. AoB Plants, 12(2), plaa007.

Ude, G. N., Kenworthy, W. J., Costa, J. M., Cregan, P. B., \& Alvernaz, J. (2003). Genetic diversity of soybean cultivars from China, Japan, North America, and North American ancestral lines determined by amplified fragment length polymorphism. Crop Science, 43(5), 1858-1867.

Yorgancılar, M., Yakışır, E., \& Erkoyuncu, M. T. (2015). Moleküler markörlerin bitki 1slahında kullanımı. Bahri Dă̆gaş Bitkisel Araştırma Dergisi, 4(2), 1-12. 